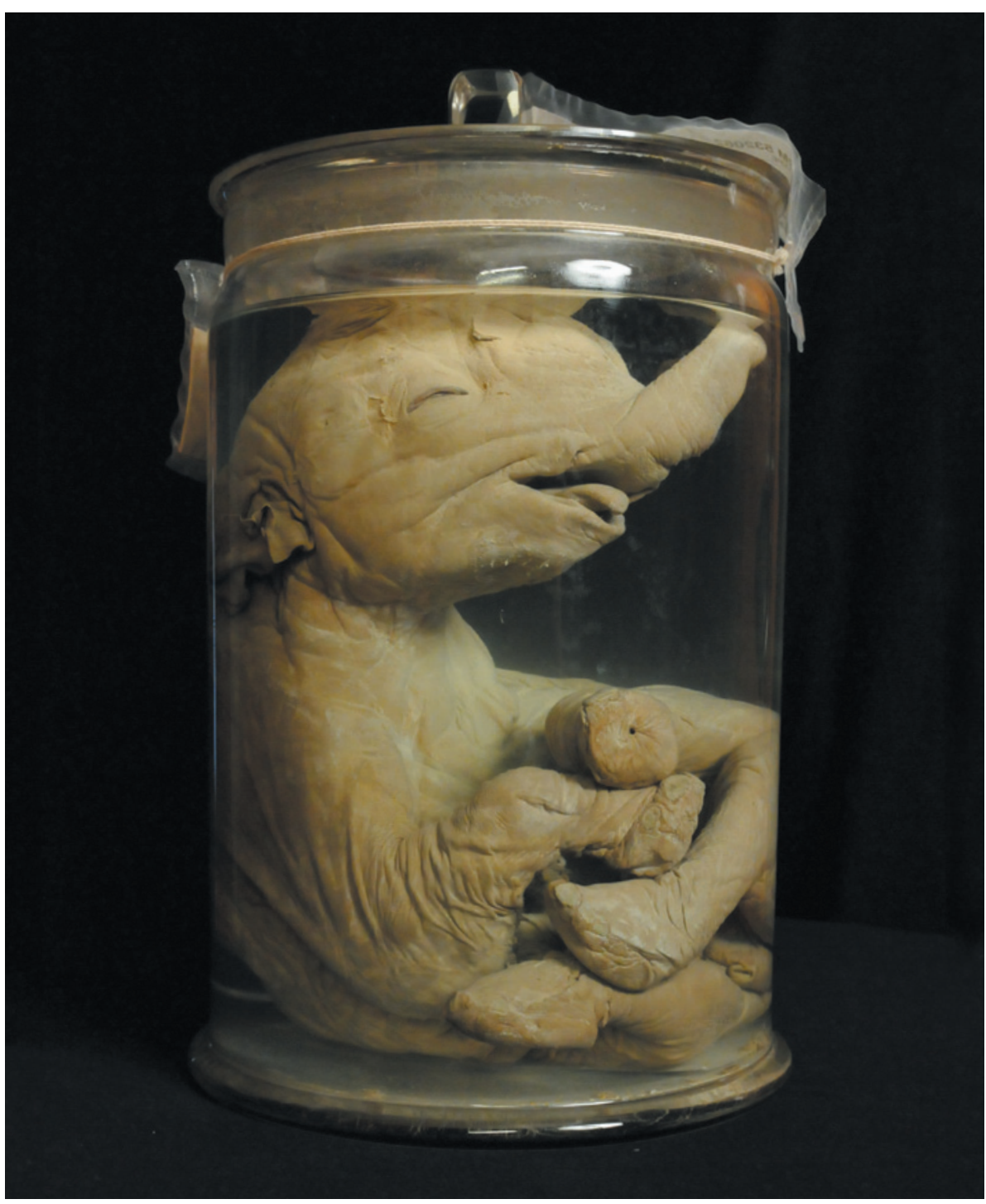

The fetus used by Carl Linnaeus as the type specimen of the Asian elephant.

PROTEOMICS

\title{
Proteins help solve taxonomy riddle
}

\section{Proteomic technique proves that 300-year-old Linnaean elephant was wrongly classified.}

\section{BY EWEN CALLAWAY}

A 300-year-old pickled fetus that was classified by Carl Linnaeus as the type specimen of the Asian elephant has been proved to be an African elephant - by the use of the emerging technology of ancient proteomics.

Evolutionary geneticist Tom Gilbert, whose
Stockholm. "Clearly it's got protein, because the damn thing still exists," Gilbert says.

The team sequenced several proteins in the specimen that were known to vary between elephant species, and each pointed to an Afri can origin for the fetus (see go.nature.com/ ivzyzm). Linnaeus assigned the elephant fetus as the type specimen of the Asian elephant (Elephas maximus), but zoologists had long suspected that it was in fact an African elephant (now called Loxodonta africana).

The work demonstrates the power of studying ancient proteins. Proteins are more resistant to degradation than DNA and could push the molecular fossil record back millions of years, as well as revealing biological insights that cannot be gleaned from genetic material alone, say scientists who study such remains.

Ancient protein analysis is not a new pursuit, says Matthew Collins, a biogeochemist at the University of York, UK. As long ago as 1954, amino acids were detected in trilobite and dinosaur fossils.

But the field took off in 2000, when Peggy Ostrom, a geochemist at Michigan State University in East Lansing, reported protein sequences from ancient bison and walrus bones up to 50,000 years old ${ }^{1}$. Her lab was the first to analyse ancient proteins using the technique of mass spectrometry, which ionizes peptide fragments and then measures their mass, enabling identification when compared with reference databases. Mass spectrometry revolutionized the field of proteomics, in which hundreds of proteins from a tissue are analysed at once, and made it possible to sequence fragmented ancient proteins.

Early efforts by Ostrom, Collins and others focused on individual proteins that are abundant in bone remains, such as collagen. "We call it the barcode of death," says Collins, who uses collagen sequencing to quickly and cheaply identify species found at archaeological sites, such as the animals used to make parchment or the horns on Viking helmets. Collagen is also remarkably stable: it has been sequenced from a 3.5-million-year-old fossil of a giant camel from the Arctic ${ }^{2}$.

But collagen differs very little between closely related animal species, making it useless as a marker for evolutionary change. "You cannot tell an ibex from a domestic goat; you cannot tell a human from a Neanderthal," Collins says. So Cappellini began developing methods to identify large numbers of different proteins in long-dead organisms. In 2012, his team identified 126 proteins from a 43,000-year-old woolly mammoth femur ${ }^{3}$. Earlier this year they sequenced 73 proteins from a 750,000-year-old horse fossil ${ }^{4}$. Both specimens also yielded DNA, but the protein data could reveal

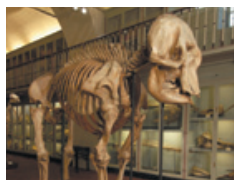

$\rightarrow$ NATURE.COM For the full story on Linnaeus's elephant, see:

go.nature.com/ivzyzm 
the additional information about which genes were expressed in bone tissue.

Like DNA sequencing, however, mass spectrometry of an ancient sample can yield an overwhelming amount of data, says Ostrom. "It can be daunting, you can get hundreds of sequences from just a single sample of a single protein, from one individual," she says. And, like ancient DNA, ancient proteins suffer from contamination and chemical modification, although less is known about those processes with proteins, Ostrom says. Another drawback is that proteomics relies on databases of protein sequences to identify the proteins found. Such databases are lacking for most modern animals, let alone their ancient ancestors.

Researchers studying ancient proteins hope to do more than just sort out museum collections, although Gilbert and Cappellini are working on plenty of these. Ancient proteins can indicate which genes were active in particular tissues from old specimens. They can also reveal phylogenetic information from specimens in which the DNA is too degraded to analyse, such as ancient samples from warm climates, where DNA doesn't last long, says Collins.
For instance, the evolutionary relationship between humans and Homo floresiensis, a short-statured human fossil from the Indonesian island of Flores, is unclear, and efforts to extract DNA have so far failed. Ancient proteins might finally place this 'hobbit' correctly on the human family tree.

1. Ostrom, P. H. et al. Geochim. Cosmochim. Acta 64 1043-1050 (2000).

2. Rybczynski, N. et al. Nature Commun 4, 1550 (2013).

3. Cappellini, E. et al. J. Proteome Res. 11, 917-926 (2012).

4. Orlando, L. et al. Nature $499,74-78$ (2013).

\section{Pathogen-research laws queried}

\section{Scientists fear EU biosafety rules could complicate publication of work on infectious diseases.}

\section{BY DECLAN BUTLER}

$\mathrm{L}$ eading virologists have written to the president of the European Commission to urge him to clarify how laws designed to curb the proliferation of biological weapons apply to the publication of research on dangerous pathogens. The move by the European Society for Virology (ESV) comes after a Dutch court in September upheld a government order that scientists who engineered forms of $\mathrm{H} 5 \mathrm{~N} 1$ avian influenza to make them transmissible between mammals needed to seek an export permit before publishing such work.

The ESV's five-page letter to José Manuel Barroso, dated 16 October, warns that the court ruling sets an unwelcome precedent. $\mathrm{H} 5 \mathrm{~N} 1$ is just one of more than 100 dangerous human, animal and plant pathogens and toxins that fall under European Union (EU) export-control legislation from 2009. This means, say the virologists, that any EU scientist who works on one of the listed pathogens could be forced to apply for an export permit before publishing their research.

They write that to better inform courts and policy-makers on scientific issues related to biosecurity laws, the European Commission should consider creating an equivalent of the US National Science Advisory Board for Biosecurity - an independent committee in Bethesda, Maryland, that advises on issues of biosecurity and dual-use research (findings that could be adapted for harmful purposes).

The ESV also backs the case of Ron Fouchier, a virologist at the Erasmus Medical Center (EMC) in Rotterdam, the Netherlands, whose team engineered the $\mathrm{H} 5 \mathrm{~N} 1$ strains. It was Fouchier's attempt to publish this work that led to the export-licence order. He has been fighting it - and on 31 October, the EMC contested the ruling in the Amsterdam Court of Appeal.

The origin of the ESV's letter dates back to 2011, when Fouchier tried to publish a paper in Science that describes how he engineered $\mathrm{H} 5 \mathrm{~N} 1$ strains that could be transmitted through the air between ferrets. This prompted a global outcry over the biosecurity of such 'gain-of-function' research - experiments designed to increase the transmissibility or pathogenicity of organisms (see nature.com/mutantflu). The Dutch government subsequently invoked European export-control legisla-

tion to oblige Fouchier and the EMC to obtain an export permit before publishing their work. Fouchier initially threatened to

\section{"If the benefits outweigh the risks, the export licence will be granted."} defy the government, but conceded and applied for a permit under protest in April last year. The government granted it a few days later.

Fouchier has argued that the EMC should not have needed a permit because the work fell under an exemption of EU export-control laws for 'basic scientific research.' He also said that the methods described had already been published. But these arguments were rejected by the court, which added in its ruling that the need to prevent the proliferation of biological weapons outweighed any delays in publication caused by government reviews of such papers.

Giorgio Palù, a virologist at the University of Padua in Italy and president of the ESV, finds it particularly unsettling that the court also ruled that it was not up to Fouchier himself to decide whether to apply for an export permit. Palù thinks this could mean that researchers working on any of the listed dangerous pathogens in the Netherlands, and perhaps in the whole of the EU, might automatically have to request export permits if they intend to publish papers on them.
But Thijs van Son, a spokesman for the Dutch foreign-affairs ministry, says that this is not the case. He adds that according to Dutch government policy, the decision on whether to apply for an export permit still lies with the researcher.

"If the researcher is convinced that the export-control legislation is not applicable to his research, he can decide not to apply for an export licence," says van Son. "However, if he is mistaken, he risks committing an offence and receiving a fine or imprisonment." Authorities, he adds, are happy to advise researchers on whether they need a permit.

Van Son also says that the ESV letter is correct that the ruling could lead to an increase in the number of papers that Dutch authorities are asked to review. But he says that the export-control law is an essential component of international efforts to halt the proliferation of chemical and biological weapons.

"The licence requirement enables the exportcontrol authorities to assess the proliferation and security risks of, for example, gain-of-function research against the public-health benefits and the freedom to share scientific information," he says. "If the benefits outweigh the risks, the export licence will be granted. This was the case with the application of Professor Fouchier."

The Dutch H5N1 case is an unprecedented test of the 2009 EU export laws, and it is not clear how other member states would handle a similar case. Ben Berkhout, a virologist at the University of Amsterdam and a member of the ESV's executive board, says that the ruling has caused uncertainty as to what it covers. "Most work on these pathogens is totally harmless," he adds. He fears that the ruling will lead to added bureaucracy, and feels that it would be much better for governments to focus on the experiments that carry the greatest risks. 